\title{
Pengaruh Profitabilitas, Leverage, Komite Audit, dan Karakter Eksekutif Terhadap Tax Avoidance
}

\author{
Syifa Pitaloka ${ }^{1}$ \\ Ni Ketut Lely Aryani Merkusiwati ${ }^{2}$ \\ ${ }^{1,2}$ Fakultas Ekonomi dan Bisnis Universitas Udayana (Unud), Bali, Indonesia \\ e-mail: syifapitaloka69@gmail.com
}

\begin{abstract}
ABSTRAK
Tax avoidance merupakan tindakan yang dilakukan untuk meminimumkan pembayaran pajak secara legal dengan memanfaatkan celah-celah dalam peraturan perpajakan. Penelitian ini bertujuan untuk menguji pengaruh profitabilitas, leverage, komite audit, dan karakter eksekutif terhadap tax avoidance. Perusahaan manufaktur yang terdaftar di Bursa Efek Indonesia (BEI) Tahun 2015-2017, dengan jumlah sampel sebanyak 68 perusahaan sehingga jumlah pengamatan sebanyak 204 dipilih sebagai sampel dalam penelitian ini. Pemilihan sampel menggunakan probability sampling dengan teknik purposive sampling. Berdasarkan hasil analisis regresi linier berganda didapatkan hasil bahwa profitabilitas, leverage, dan karakter eksekutif berpengaruh positif terhadap tax avoidance, sedangkan komite audit berpengaruh negatif terhadap tax avoidance.
\end{abstract}

Kata Kunci: Tax avoidance, profitabilitas, leverage, komite audit, karakter eksekutif

\section{ABSTRACT}

Tax avoidance is an action taken to minimize tax payments legally by utilizing loopholes in tax regulations. This study aims to examine the effect of profitability, leverage, audit committee, and executive character on tax avoidance. Manufacturing companies listed on the Indonesia Stock Exchange (IDX) in 2015-2017, with a total sample of 68 companies so that the number of observations was 204 selected as samples in this study. The sample selection uses probability sampling with purposive sampling technique. Based on the result of multiple linear regression analysis the results show that profitability, leverage, and executive character have a positive effect on tax avoidance, while the audit committee has a negative effect on tax avoidance.

Keywords: Tax avoidance, profitability, leverage, audit committee, character executive

\section{PENDAHULUAN}

Pajak merupakan sumber penerimaan utama negara yang digunakan untuk pembangunan negara. Menurut Undang-Undang Nomor 16 tahun 2009 tentang Ketentuan Umum dan Tata Cara Perpajakan pasal 1 ayat 1 pajak merupakan kontribusi wajib kepada negara yang tertuang oleh orang pribadi atau badan yang bersifat memaksa berdasarkan undang-undang, dengan tidak mendapatkan imbalan secara langsung dan digunakan untuk keperluan negara. Oleh karena itu, 
Syfa Pitaloka dan Ni Ketut Lely Aryani Merkusiawati. Pengaruh ...

negara selalu berupaya untuk mengoptimalkan penerimaan pajak. Adanya ketidakpatuhan wajib pajak dalam menyetorkan pajak dapat menimbulkan adanya praktik yang dikenal sebagai istilah tax avoidance (penghindaran pajak).

Tax avoidance adalah suatu tindakan yang dilakukan untuk mengurangi atau meminimalkan kewajiban pajak dengan memanfaatkan celah-celah dalam ketentuan perpajakan (Jacob, 2014). Pemerintah menginginkan peningkatan penerimaan dari sektor pajak untuk membiayai pembangunan negara. Bertentangan dengan pemerintah, perusahaaan berusaha merancang dan menerapkan praktik manajemen mereka sedemikian rupa agar meminimalkan beban pajaknya (Mehrani \& Seyyedi, 2014). Perbedaan kepentingan inilah yang menyebabkan perusahaan berusaha untuk membayar pajak seminimal mungkin yaitu dengan melakukan tax avoidance.

Fenomena tax avoidance yang terjadi di beberapa perusahaan di Indonesia diantaranya menimpa PT Asian Agri Tbk, PT Coca Cola Indonesia (CCI), PT Kaltim Prima Coal (KCP), PT Bumi Resources, dan PT Arutmin Indonesia. Berdasarkan Putusan MA No.2239K/PID.SUS/2012 tanggal 18 Desember 2012, PT Asian Agri Tbk dinyatakan kurang membayar pajak pada tahun 2002-2005 sebesar $\mathrm{Rp}$ 1,25 triliun dan denda $\mathrm{Rp}$ 1,25 triliun sehingga total yang harus dibayarkan sebesar Rp 2,5 triliun (Kompas.com, 2014). Pada tahun 2002-2006 PT Coca Cola Indonesia diduga mengakali pajak sehingga menimbulkan kekurangan pembayaran pajak sebesar Rp 49,24 miliar (Kompas.com., 2014). Pada tahun 2007 PT Kaltim Prima Coal (KCP) melakukan tax avoidance sebesar Rp 1,5 triliun. Pada tahun yang sama PT Bumi Reasources dan PT Arutmin Indonesia 
juga melakukan praktik tax avoidance masing-masing sebesar Rp 376 miliar dan Rp 300 miliar (Tempo.co, 2010).

Praktik tax avoidance lain juga ditemukan pada PT Pabrik Kertas Tjiwi Kimia Tbk dan PT Kalbe Farma Tbk. Menurut Laporan Keuangan PT Pabrik Kertas Tjiwi Kimia Tbk tahun 2015, perusahaan menerima Surat Ketetapan Pajak Kurang Bayar (SKPKB) pada tanggal 11 Desember 2015 yang menyatakan perusahaan memiliki kurang bayar pajak atas pajak penghasilan badan tahun pajak 2010 sebesar Rp 3,5 miliar. Menurut Laporan Keuangan PT Kalbe Farma tbk tahun 2017, perusahaan menerima SKPKB yang menyatakan perusahaan memiliki kurang bayar pajak sebesar Rp 576.850.595 atas pajak penghasilan dan PPN untuk tahun fiskal 2016. Penerbitan SKPKB ini mengindikasikan bahwa perusahaan berusaha untuk meminimumkan beban pajaknya dengan melakukan praktik tax avoidance.

Salah satu faktor yang menentukan terjadinya tax avoidance adalah profitabilitas. Profitabilitas menunjukkan kemampuan suatu perusahaan dalam menghasilkan laba dengan menggunakan total aset yang dimilikinya. Salah satu rasio dari profitabilitas adalah return on assets (ROA). Semakin tinggi rasio ROA maka semakin tinggi pula praktik tax avoidance yang dilakukan oleh perusahaan, hal ini disebabkan perusahaan dengan laba yang tinggi akan dapat memanfaatkan celah dalam pengelolaan beban pajaknya. Penelitian yang dilakukan oleh Darmawan \& Sukartha (2014), Dewinta \& Ery (2016), dan Puspita \& Naniek (2017) menunjukkan ROA berpengaruh positif terhadap tax avoidance. Penelitian lain yang dilakukan oleh (Maharani \& Suardana, 2014) menunjukkan bahwa ROA 
berpengaruh negatif terhadap tax avoidance. Bertentangan dengan (Rachmitasari, 2015) yang menyatakan ROA tidak berpengaruh terhadap tax avoidance. Berkaitan dengan perbedaan hasil tersebut, penelitian ini kembali menguji pengaruh profitabilitas terhadap tax avoidance.

Leverage juga merupakan faktor yang dapat mempengaruhi praktik tax avoidance. Leverage adalah ukuran seberapa besar aset yang dimiliki perusahaan dibiayai oleh utang. Perusahaan dengan banyak hutang cenderung mengambil keuntungan dari karakteristik utang untuk menghindari beban pajak perusahaan yang signifikan (Anouar \& Houria, 2017). Penggunaan utang akan menimbulkan beban tetap (fixed rate return) yang disebut dengan bunga. Adanya bunga akan menjadi pengurang dalam penghasilan kena pajak perusahaan. Perusahaan yang menggunakan hutang sebagai sumber pendanaan mayoritas akan memiliki laba sebelum kena pajak yang lebih kecil dibandingkan dengan perusahaan yang menggunakan penerbitan saham sebagai sumber pendanaan mayoritasnya. Semakin besar penggunaan utang maka laba kena pajak akan menjadi lebih kecil karena insentif pajak atas bunga utang semakin besar. Hal tersebut dapat mengurangi kewajiban pajak perusahaan dan digolongkan sebagai tindakan tax avoidance.

Penelitian yang dilakukan oleh Rachmitasari (2015), Nursari \& Sukarmanto (2016), Wijayanti \& Merkusiwati (2017), Daneshvar et al. (2017), serta Nugrahitha \& S. (2018) menyatakan bahwa leverage berpengaruh positif terhadap tax avoidance. Penelitian lain yang dilakukan oleh Swingly \& Sukartha (2015), Putri (2017) menyatakan bahwa leverage berpengaruh negatif terhadap tax 
avoidance. Bertentangan dengan penelitian yang dilakukan oleh Darmawan \& Sukartha (2014), serta Putra \& Merkusiwati (2016) yang menunjukkan bahwa leverage tidak berpengaruh signifikan terhadap tax avoidance. Berkaitan dengan perbedaan hasil tersebut, penelitian ini kembali menguji pengaruh leverage terhadap tax avoidance.

Hal lain yang dapat mempengaruhi terjadinya tax avoidance adalah komite audit. Menurut Peraturan Otoritas Jasa Keuangan No 55/POJK.04/2015 Tentang Pembentukan dan Pedoman Pelaksanaan Kerja Komite Audit Pasal 4 dijelaskan bahwa komite audit paling sedikit terdiri dari tiga orang anggota yang berasal dari komisaris independen dan pihak di luar emiten atau perusahaan publik. Komite audit dalam suatu perusahaan berperan untuk mendukung dewan komisaris dalam memonitor manajemen menyusun laporan keuangan perusahaan. Komite audit juga berperan dalam mengendalikan manajer demi meningkatkan laba perusahaan dimana manajer perusahaan yang nantinya cenderung menekan biaya pajaknya, hal tersebut yang akan mendorong manajemen melakukan praktik tax avoidance (Fadhilah, 2014). Komite audit dapat mencegah segala perilaku atau tindakan yang menyimpang terkait laporan keuangan perusahaan. Adanya komite audit dalam suatu perusahaan dapat meminimalisasi terjadinya praktik tax avoidance.

Penelitian yang dilakukan oleh Dewi \& Jati (2014), Maharani \& Suardana (2014), Winata (2014), Diantari \& Ulupui (2016), serta Noriska et al. (2017) menyatakan bahwa komite audit berpengaruh negatif terhadap aktivitas tax avoidance. Semakin banyak jumlah komite audit pada suatu perusahaan maka kebijakan untuk melakukan tax avoidance akan semakin kecil. Penelitian lain 
yang dilakukan oleh Marfirah \& BZ (2016) menyatakan bahwa komite audit berpengaruh positif terhadap tax avoidance. Bertentangan dengan penelitian yang dilakukan oleh Swingly \& Sukartha (2015) yang menyatakan bahwa komite audit tidak berpengaruh terhadap tax avoidance. Berkaitan dengan perbedaan hasil tersebut, penelitian ini kembali menguji pengaruh komite audit terhadap tax avoidance.

Faktor lain yang dapat memengaruhi terjadinya tax avoidance adalah karakter eksekutif. Eksekutif yang merupakan pimpinan perusahaan baik secara langsung maupun tidak langsung memiliki pengaruh terhadap keputusan yang terjadi dalam perusahaan, termasuk keputusan mengenai tax avoidance yang dilakukan oleh perusahaan (Hanafi \& Harto, 2014). Pimpinan perusahaan sebagai pengambil kebijakan dan keputusan dalam perusahaan tentu memiliki karakter yang berbeda-beda. Seorang pemimpin perusahaan dapat memiliki karakter yang risk taker atau risk averse yang tercermin dari besar kecilnya risiko perusahaan (Dewi \& Jati, 2014). Semakin eksekutif bersifat risk taker maka akan semakin tinggi tingkat tax avoidance yang dilakukan perusahaan (Hanafi \& Harto, 2014).

Beberapa eksekutif memandang praktik minimalisasi pajak sebagai cara yang dapat diterima untuk melakukan operasi bisnis dan menerapkan strategi mengurangi beban pajak perusahaan (Hasan et al., 2017). Karakter eksekutif dianggap faktor penting yang dapat memengaruhi kebijakan yang akan diambil oleh eksekutif. Hal ini dikarenakan eksekutif sebagai agen perusahaan memiliki tanggung jawab untuk memaksimalkan utilitas para stakeholders melalui keputusan yang diambilnya dengan mempertimbangkan berbagai risiko yang akan 
timbul. Penelitian yang dilakukan oleh Hanafi \& Harto (2014), Dewi \& Jati (2014), Butje \& Tjondro (2014), Swingly \& Sukartha (2015) dan Wiguna \& Jati (2017) menyatakan bahwa karakter eksekutif berpengaruh positif terhadap tax avoidance. Penelitian lain yang dilakukan oleh Kartana \& Wulandari (2018) menyatakan bahwa karakter eksekutif tidak berpengaruh terhadap tax avoidance. Berkaitan dengan perbedaan hasil tersebut penelitian ini kembali menguji pengaruh karakter eksekutif terhadap tax avoidance.

Penelitian ini menggunakan perusahaan manufaktur tahun 2015-2017 dikarenakan perusahaan manufaktur merupakan salah satu wajib pajak yang sering difokuskan dalam pemeriksaan Direktorat Jenderal Pajak (Mulyani et al., 2014), perusahaan manufaktur merupakan perusahaan yang aktivitas usahanya menyeluruh mulai dari pembelian bahan baku diolah hingga menjadi barang jadi yang siap dijual di pasaran sehingga aktivitas usahanya sebagian besar terkait dengan aspek perpajakan, serta perusahaan manufaktur merupakan salah satu sektor yang berkontribusi besar pada penerimaan pajak negara selain selain sektor perkebunan, keuangan, dan pertambangan. Realisasi penerimaan pajak dari sektor industri manufaktur mencapai Rp 224,95 triliun hingga kuartal ketiga tahun 2017 atau meningkat 16,63 persen dibandingkan dengan periode yang sama tahun 2016 (Cnnindonesia.com, 2017). Sepanjang tahun 2017 penerimaan pajak sektor manufaktur tercatat tumbuh sebesar 31 persen. Menurut Menteri Perindustrian Airlangga Hartato, perusahaan manufaktur tidak hanya sebagai penyumbang terbesar pada Produk Domestik Bruto (PDB) nasional tetapi perusahaan 
manufaktur juga mampu memberikan kontribusi tertinggi sebagai penyetor pajak (Kemenperin.go.id, 2018).

Return on Assets (ROA) merupakan salah satu rasio profitabilitas. ROA digunakan untuk mengukur kemampuan perusahaan dalam menghasilkan laba berdasarkan aset yang dimiliki. Semakin tinggi nilai ROA, maka semakin besar juga laba yang diperoleh perusahaan. Teori agensi akan memacu para agen untuk meningkatkan laba perusahaan. Ketika laba yang diperoleh membesar, maka jumlah pajak penghasilan akan meningkat sesuai dengan peningkatan laba perusahaan. Agen dalam teori agensi akan berusaha mengelola beban pajaknya agar tidak mengurangi kompensasi kinerja agen sebagai akibat dari berkurangnya laba perusahaan oleh beban pajak. Perusahaan dengan tingkat profitabilitas yang tinggi dapat membayar pajak lebih tinggi dari perusahaan yang memiliki profitabilitas yang rendah. Dengan demikian dapat disimpulkan bahwa perusahaan yang memiliki profitabilitas yang tinggi akan cenderung melakukan praktik tax avoidance untuk meminimalkan beban pajaknya. Tingkat profitabilitas perusahaan berpengaruh signifikan dengan tarif pajak efektif karena semakin efisien perusahaan, maka perusahaan akan membayar pajak yang lebih sedikit sehingga tarif pajak efektif perusahaan tersebut menjadi lebih rendah (Derashida \& Zhang, 2003). Perusahaan dengan tingkat efisiensi dan pendapatan yang besar cenderung memiliki beban pajak yang rendah karena perusahaan tersebut berhasil memanfaatkan keuntungan dari adanya insentif dan pengurang pajak yang lain. Penelitian yang dilakukan oleh Darmawan \& Sukartha (2014), Dewinta \& Ery (2016), dan Puspita \& Naniek (2017)menyatakan bahwa ROA memiliki pengaruh 
positif pada tax avoidance. Berdasarkan uraian tersebut, maka hipotesis dalam penelitian ini sebagai berikut:

$\mathrm{H}_{1}$ : Profitabilitas berpengaruh positif terhadap tax avoidance.

Kebijakan pendanaan perusahaan dapat menjadi gambaran tax avoidance terkait dengan tarif pajak efektif karena terdapat peraturan perpajakan terkait kebijakan struktur pendanaan perusahaan. Kebijakan pendanaan tersebut salah satunya adalah leverage. Perusahaan yang memilih menggunakan leverage sebagai pendanaan perusahaan akan mengakibatkan munculnya beban bunga yang dapat menjadi pengurang laba kena pajak. Penambahan jumlah utang akan mengakibatkan menambahnya beban bunga yang harus dibayar oleh perusahaan. Beban bunga akan mengurangi laba sebelum kena pajak perusahaan, sehingga beban pajak yang harus dibayar perusahaan akan menjadi berkurang. Semakin besar penggunaan utang maka laba kena pajak akan menjadi lebih kecil karena insentif pajak atas bunga utang semakin besar sehingga menunjukkan praktik tax avoidance yang tinggi. Hal tersebut dapat mengurangi kewajiban pajak perusahaan dan digolongkan sebagai tindakan tax avoidance. Penelitian yang dilakukan oleh Rachmitasari (2015), Nursari \& Sukarmanto (2016), Wijayanti \& Merkusiwati (2017), Daneshvar et al. (2017), serta Nugrahitha \& S. (2018) menyatakan bahwa leverage berpengaruh positif terhadap tax avoidance.

Berdasarkan uraian tersebut, maka hipotesis dalam penelitian ini sebagai berikut:

$\mathrm{H}_{2}$ : Leverage berpengaruh positif terhadap tax avoidance.

Komite audit mempunyai peran dalam membantu dewan komisaris melakukan monitoring serta memberi pertimbangan kepada manajemen pada 
pengendalian intern yang berlangsung di dalam perusahaan agar tidak terjadi asimetri informasi. Penelitian yang dilakukan Pohan (2009) menyatakan bahwa jika jumlah komite audit dalam suatu perusahaan tidak sesuai dengan peraturan BEI yang mengharuskan minimal terdapat tiga orang maka akan meningkatkan tindakan manajemen dalam melakukan praktik tax avoidance. Penelitian yang dilakukan oleh Dewi \& Jati (2014), Winata (2014), dan Rachmitasari (2015), Diantari \& Ulupui (2016), serta Noriska et al. (2017) menyatakan bahwa keberadaan komite audit memiliki pengaruh negatif terhadap tax avoidance. Semakin tinggi keberadaan komite audit dalam perusahaan akan memperkecil kemungkinan terjadinya aktivitas tax avoidance. Berdasarkan uraian tersebut, maka hipotesis dalam penelitian ini sebagai berikut:

$\mathrm{H}_{3}$ : Komite Audit berpengaruh negatif terhadap tax avoidance.

Eksekutif sebagai pimpinan perusahaan baik secara langsung maupun tidak langsung memiliki pengaruh terhadap segala keputusan yang terjadi dalam perusahaan, termasuk keputusan melakukan praktik tax avoidance (Swingly \& Sukartha, 2015). Eksekutif memiliki dua karakter yaitu risk taker dan risk averse dalam mengambil keputusan. Semakin eksekutif bersifat risk taker, nilai CETR akan semakin rendah yang mengindikasikan tax avoidance semakin tinggi. Dapat disimpulkan bahwa semakin eksekutif bersifat risk taker semakin besar tingkat tax avoidance perusahaan begitu pula sebaliknya (Carolina et al., 2014). Berdasarkan penelitian yang dilakukan oleh Hanafi \& Harto (2014), Dewi \& Jati (2014), Butje \& Tjondro (2014), serta Wiguna \& Jati (2017) menyatakan bahwa karakter 
eksekutif berpengaruh positif pada tax avoidance. Berdasarkan uraian tersebut, maka hipotesis dalam penelitian ini sebagai berikut:

$\mathrm{H}_{4}$ : Karakter eksekutif berpengaruh positif terhadap tax avoidance.

\section{METODE PENELITIAN}

Lokasi penelitian merupakan suatu tempat atau wilayah dimana penelitian tersebut akan dilakukan. Lokasi penelitian ini dilakukan pada perusahaan manufaktur yang terdaftar di Bursa Efek Indonesia (BEI) pada tahun 2015-2017 dikarenakan perusahaan manufaktur merupakan salah satu wajib pajak yang sering difokuskan dalam pemeriksaan Direktorat Jenderal Pajak (Mulyani et al., 2014), perusahaan manufaktur merupakan perusahaan yang aktivitas usahanya menyeluruh mulai dari pembelian bahan baku diolah hingga menjadi barang jadi yang siap dijual di pasaran sehingga aktivitas usahanya sebagian besar terkait dengan aspek perpajakan, serta perusahaan manufaktur merupakan salah satu sektor yang berkontribusi besar pada penerimaan pajak negara selain selain sektor perkebunan, keuangan, dan pertambangan. Penelitian ini dilakukan dengan mengakses situs resmi BEI yaitu www.idx.co.id untuk mendapatkan laporan tahunan dari masing-masing perusahaan yang menjadi sampel penelitian. Ruang lingkup penelitian ini hanya membatasi pembahasannya pada pengujian apakah profitabilitas, leverage, komite audit, dan karakter eksekutif berpengaruh pada tax avoidance.

Rumus yang digunakan untuk menghitung CETR menurut Dyreng, et al. (2010) adalah sebagai berikut: 
$\mathrm{CETR}=\frac{\text { Pembayaran Pajak }}{\text { Laba Sebelum Pajak }}$

Adapun rumus untuk menghitung ROA menurut Jeong Ho (2017) adalah sebagai berikut:

Return on Assets $(R O A)=\frac{\text { Laba Bersih }}{\text { Total Aset }}$.

Menurut Rachmitasari (2015) rumus yang digunakan untuk menghitung leverage adalah sebagai berikut:

Debt to Assets Ratio $(D A R)=\frac{\text { Total Utang }}{\text { Total Asset }}$.

Adapun rumus standar deviasi adalah sebagai berikut:

$$
\mathrm{RISK}=\sqrt{\sum_{T=1}^{r}\left(E-1 / T \sum_{T=1}^{r} E\right)^{2} /(T-1)} .
$$

Keterangan:

$\mathrm{E} \quad=\mathrm{EBITDA} /$ Total Asset

$\mathrm{T}=$ Total Sampel

Populasi dalam penelitian ini adalah seluruh perusahaan manufaktur yang terdaftar di Bursa Efek Indonesia (BEI) tahun 2015-2017. Alasan penggunaan perusahaan manufaktur dikarenakan perusahaan manufaktur merupakan perusahaan yang paling banyak terdaftar di BEI dan perusahaan manufaktur berpotensi menjadi penyumbang pajak terbesar yang akan menambah pemasukan negara.

Teknik analisa pada penelitian ini menggunakan analisis regresi linier berganda. Regresi linier berganda merupakan alat analisis yang digunakan untuk mengukur pengaruh lebih dari satu variabel independen terhadap variabel dependen. Adapun model regresi dirumuskan dengan persamaan sebagai berikut: 
CETR $=\alpha+\beta_{1} X_{1}+\beta_{2} X_{2}+\beta_{3} X_{3}+\beta_{4} X_{4}+\epsilon$.

Keterangan:

\begin{tabular}{|c|c|}
\hline Y & $=$ Tax avoidance \\
\hline$\alpha$ & $=$ Konstanta \\
\hline$\beta_{1}, \beta_{2}, \beta_{3}, \operatorname{dan} \beta_{4}$ & $=$ Koefisien regresi \\
\hline$X_{1}$ & $=$ Profitabilitas \\
\hline $\mathrm{X}_{2}$ & $=$ Leverage \\
\hline$X_{3}$ & $=$ Komite Audit \\
\hline $\mathrm{X}_{4}$ & $=$ Karakter Eksekuti \\
\hline & $=$ error term \\
\hline
\end{tabular}

\section{HASIL DAN PEMBAHASAN}

Statistik deskriptif disajikan untuk memberikan informasi mengenai karakteristik variabel-variabel penelitian yang terdiri dari nilai minimum, nilai maksimum, rata-rata dan standar deviasi. Adapun hasil uji statistik deskriptif dalam penelitian ini dapat dilihat pada Tabel 1 berikut.

Tabel 1.

Hasil Uji Statistik Deskriptif

\begin{tabular}{lrrrrr}
\hline & N & Minimum & Maximum & Mean & Std. Deviation \\
\hline X1 & 204 & 0,0002 & 0,5267 & 0,089656 & 0,0853259 \\
X2 & 204 & 0,0707 & 0,8197 & 0,385416 & 0,1755161 \\
X3 & 204 & 3,0000 & 5,0000 & 3,107843 & 0,3553078 \\
X4 & 204 & 0,0000 & 0,0004 & 0,000195 & 0,0000889 \\
Y & 204 & 0,0124 & 0,9220 & 0,279501 & 0,1307058 \\
Valid N (listwise) & 204 & & & & \\
\hline \multicolumn{2}{l}{ Sumber: Data diolah, 2018}
\end{tabular}

Pengukuran tax avoidance dalam penelitian ini menggunakan proksi Cash Effective Tax Rate (CETR) yaitu pembayaran pajak dibagi dengan laba sebelum pajak. Hasil dari analisis statistik deskriptif menunjukkan nilai rata-rata sebesar 0,279501 dengan nilai standar devisiasi 0,1307058. Nilai maksimum sebesar 0,9220 dimiliki oleh perusahaan dengan kode SQBI dan SQBB pada tahun 2016, sedangkan nilai minimum sebesar 0,0124 dimiliki oleh perusahaan dengan kode KBLI pada tahun 2017. 
Profitabilitas dalam penelitian ini diukur dengan Return on Asset (ROA). Adapun ROA dihitung dengan rumus laba bersih dibagi dengan total aset. Hasil dari analisis statistik deskriptif menunjukkan rata-rata nilai ROA sebesar 0,089656 dengan nilai standar deviasi sebesar 0,0853259. Nilai ROA tertinggi sebesar 0,5267 diperoleh oleh perusahaan dengan kode MERK pada tahun 2017, sedangkan nilai ROA terendah sebesar 0,0002 dimiliki oleh perusahaan dengan kode UNVR pada tahun 2015.

Leverage dalam penelitian ini dihitung dengan membandingkan total utang dengan total aset yang dimiliki perusahaan. Hasil dari analisis statistik deskriptif menunjukkan rata-rata nilai leverage sebesar 0,385416 dengan standar deviasi 0,1755161. Nilai leverage tertinggi sebesar 0,8197 dimiliki oleh perusahaan dengan kode IMPC pada tahun 2015, sedangkan nilai leverage terendah sebesar 0,0707 dimiliki oleh perusahaan dengan kode SCCO pada tahun 2015.

Komite audit dalam penelitian ini dihitung dari jumlah anggota komite audit yang terdapat dalam suatu perusahaan. Hasil analisis statistik deskriptif menunjukkan rata-rata nilai komite audit sebesar 3,107843 dengan standar deviasi 0,3553078. Perusahaan yang memiliki komite audit terbesar adalah perusahaan dengan kode CPIN pada tahun 2015-2017 yaitu sebanyak 5 orang. Perusahaan yang memiliki komite audit terkecil sebanyak 3 orang dimiliki oleh 58 perusahaan pada tahun 2015-2017.

Karakter eksekutif dalam penelitian ini diukur menggunakan risiko perusahaan (corporate risk). Adapun risiko perusahaan diukur dengan menghitung standar deviasi dari Earning Before Interest, Tax, Depreciation, and 
Amortization (EBITDA) dibagi total aset. Hasil analisis statistik deskriptif menunjukkan rata-rata nilai karakter eksekutif sebesar 0,000195 dengan standar deviasi 0,0000889. Nilai karakter eksekutif tertinggi sebesar 0,0004 dimiliki oleh perusahaan dengan kode UNIT pada tahun 2017, sedangkan nilai karakter eksekutif terendah sebesar 0,0000 dimiliki oleh perusahaan dengan kode ISSP pada tahun 2015 .

Hasil uji Kolgomorov-Smirnov (K-S) dapat dilihat pada Tabel 2 berikut.

Tabel 2.

Hasil Uji Kolgomorov-Smirnov (K-S)

\begin{tabular}{llr}
\hline $\mathrm{N}$ & & Unstandardized Residual \\
Normal Parameters & & 204 \\
& Mean & 0,0000000 \\
Most Extreme & Std. Deviation & 0,12227811 \\
Differences & Absolute & 0,160 \\
& Positive & 0,160 \\
Kolmogorov-Smirnov Z & Negative & $-0,090$ \\
Asymp. Sig. (2-tailed) & & 0,293 \\
\hline Sumber: Data diolah, 2018 & & 0,447 \\
\hline
\end{tabular}

Sumber: Data diolah, 2018

Berdasarkan Tabel 2 dapat dilihat bahwa nilai Asymp. Sig (2-tailed) 0,447 lebih besar dari $\alpha=0,05$, sehingga data yang digunakan berdistribusi normal.

Hasil uji multikolinieritas dapat dilihat pada Tabel 3 berikut.

Tabel 3.

Hasil Uji Multikolinearitas

\begin{tabular}{|c|c|c|}
\hline \multirow[b]{2}{*}{ Model } & \multicolumn{2}{|c|}{ Collinearity Statistics } \\
\hline & Tolerance & VIF \\
\hline $\mathrm{X} 1$ & 0,298 & 3,360 \\
\hline $\mathrm{X} 2$ & 0,952 & 1,050 \\
\hline X3 & 0,960 & 1,042 \\
\hline $\mathrm{X} 4$ & 0,293 & 3,418 \\
\hline
\end{tabular}

Sumber: Data diolah, 2018

Berdasarkan Tabel 3 dapat dilihat nilai tolerance untuk setiap variabel bebas lebih besar dari 0,10 dan nilai VIF-nya lebih lecil dari 10 sehingga model regresi dapat dikatakan bebas dari multikolinieritas. 
Uji yang digunakan adalah uji Glejser. Jika tingkat signifikansi berada di atas 0,05 maka model regresi ini terbebas dari masalah heteroskedastisitas. Hasil uji heteroskedastisitas dapat dilihat pada Tabel 4 berikut.

Tabel 4.

Hasil Uji Heteroskedastisitas

\begin{tabular}{|c|c|c|}
\hline Variabel & Sig. & Keterangan \\
\hline $\mathrm{X}_{1}$ & 0,164 & Bebas heteroskedastisitas \\
\hline $\mathrm{X}_{2}$ & 0,333 & Bebas heteroskedastisitas \\
\hline$X_{3}$ & 0,461 & Bebas heteroskedastisitas \\
\hline $\mathrm{X}_{4}$ & 0,099 & Bebas heteroskedastisitas \\
\hline
\end{tabular}

Sumber: Data diolah, 2018

Berdasarkan Tabel 4 di atas menunjukkan keseluruhan variabel bebas memiliki nilai signifikansi melebihi 0,05 sehingga data penelitian dapat disimpulkan terbebas dari gejala heteroskedastisitas.

Pengukuran data yang terkena autokolerasi atau tidak dapat dilihat dari nilai Durbin-Watson (DW-test). Hasil uji autokolerasi dapat dilihat pada Tabel 5 berikut.

Tabel 5.

Hasil Uji Autokolerasi

\begin{tabular}{cccccc}
\hline Model & $\mathrm{R}$ & R Square & $\begin{array}{c}\text { Adjusted R } \\
\text { Square }\end{array}$ & $\begin{array}{c}\text { Std. Error of the } \\
\text { Estimate }\end{array}$ & Durbin Watson \\
\hline 1 & $0,73^{\mathrm{a}}$ & 0,537 & 0,537 & 0,1235009 & 1,943 \\
\hline Sumber: Data diolah, 2018 & & & & &
\end{tabular}

Berdasarkan Tabel 5 dapat dilihat nilai Durbin-Watson (dw) sebesar 1,943.

Oleh karena jumlah sampel $n=204$ dan $k=4$ variabel bebas, diperoleh nilai $d_{L}=$ 1,728 dan $\mathrm{d}_{\mathrm{u}}=1,810$ sehingga didapat nilai $4-\mathrm{d}_{\mathrm{u}}=2,19$ maka dapat dirumuskan kriteria $d_{u}<d w<4-d_{u}$ yaitu $1,810<1,943<2,19$. Hal ini menunjukkan bahwa data yang digunakan dalam penelitian ini bebas dari gejala autokolerasi.

Hasil dari analisis regresi linier berganda ditunjukkan pada Tabel 6 sebagai berikut. 
Tabel 6.

Hasil Regresi Linier Berganda

\begin{tabular}{|c|c|c|c|c|c|c|}
\hline & \multicolumn{3}{|c|}{ Unstandardized Coefficients } & \multirow{2}{*}{$\begin{array}{c}\text { Standardized } \\
\text { Coefficients } \\
\text { Beta }\end{array}$} & \multirow[b]{2}{*}{$\mathrm{t}$} & \multirow[b]{2}{*}{ Sig. } \\
\hline & Model & B & Std. Error & & & \\
\hline 1 & (Constant) & 0,380 & 0,080 & & 4,725 & 0,000 \\
\hline & $\mathrm{X} 1$ & 0,287 & 0,086 & 0,188 & 3,335 & 0,012 \\
\hline & $\mathrm{X} 2$ & 0,106 & 0,051 & 0,143 & 2,100 & 0,037 \\
\hline & X3 & $-0,026$ & 0,012 & $-0,071$ & $-2,103$ & 0,039 \\
\hline & $\mathrm{X} 4$ & 174,350 & 80,213 & 0,119 & 2,174 & 0,023 \\
\hline
\end{tabular}

Sumber: Data diolah, 2018

Berdasarkan Tabel 6 dapat disusun persamaan regresi linier berganda sebagai berikut.

$$
\mathrm{Y}=0,380+0,287 X_{1}+0,106 X_{2}-0,026 X_{3}+174,350 X_{4}
$$

Keterangan:

$\mathrm{Y}=$ Cash Efective Tax Rate (CETR) sebagai proksi tax avoidance

$\alpha=$ Konstanta

$\beta=$ Koefisien regresi

$\epsilon=$ Standar error

$\mathrm{X}_{1}=$ Profitabilitas

$\mathrm{X}_{2}=$ Leverage

$\mathrm{X}_{3}=$ Komite Audit

$\mathrm{X}_{4}=$ Karakter Eksekutif

Nilai konstanta sebesar 0,380 menunjukkan bahwa apabila nilai profitabilitas $\left(\mathrm{X}_{1}\right)$, leverage $\left(\mathrm{X}_{2}\right)$, komite audit $\left(\mathrm{X}_{3}\right)$ dan karakter eksekutif $\left(\mathrm{X}_{4}\right)$ adalah 0 , mengakibatkan nilai cash effective tax rate sebagai proksi tax avoidance (Y) turun sebesar 0,380.

Koefisien regresi profitabilitas $\left(\mathrm{X}_{1}\right)$ sebesar 0,287 menunjukkan bahwa peningkatan profitabilitas sebesar 1 persen akan meningkatkan nilai cash effective tax rate sebagai proksi tax avoidance (Y) sebesar 0,287 atau 28,7 persen dengan syarat variabel bebas lainnya konstan.

Koefisien regresi leverage $\left(\mathrm{X}_{2}\right)$ sebesar 0,106 menunjukkan bahwa peningkatan leverage sebesar 1 persen akan meningkatkan nilai cash effective tax 
rate sebagai proksi tax avoidance (Y) sebesar 0,106 atau 10,6 persen dengan syarat variabel bebas lainnya konstan.

Koefisien regresi komite audit $\left(\mathrm{X}_{3}\right)$ sebesar $-0,026$ menunjukkan bahwa apabila komite audit meningkat sebesar 1 persen maka nilai cash effective tax rate sebagai proksi tax avoidance (Y) akan menurun sebesar 0,026 atau 2,6 persen dengan syarat variabel bebas lainnya konstan.

Koefisien regresi karakter eksekutif $\left(\mathrm{X}_{4}\right)$ sebesar 174,350 menunjukkan bahwa peningkatan karakter eksekutif sebesar 1 persen akan meningkatkan nilai cash effective tax rate sebagai proksi tax avoidance (Y) sebesar 174,350 atau 17.435 persen dengan syarat variabel bebas lainnya konstan.

Berdasarkan hasil uji statistik t pada Tabel 6 diketahui bahwa variabel profitabilitas memiliki t tabel sebesar 3,335 dengan koefisien sebesar 0,287 dan tingkat signifikansi 0,012 . Nilai sig. $=0,012<\alpha=0,05$. Berdasarkan nilai yang diperoleh dapat disimpulkan bahwa hipotesis 1 diterima yang menunjukkan bahwa variabel profitabilitas berpengaruh positif terhadap tax avoidance.

Berdasarkan hasil uji statistik t pada tabel 6 diketahui bahwa variabel leverage memiliki t tabel sebesar 2,100 dengan koefisien sebesar 0,106 dan tingkat signifikansi 0,037 . Nilai sig. $=0,037<\alpha=0,05$. Berdasarkan nilai yang diperoleh dapat disimpulkan bahwa hipotesis 2 diterima yang menunjukkan bahwa variabel leverage berpengaruh positif terhadap tax avoidance.

Berdasarkan hasil uji statistik t pada tabel 6 diketahui bahwa variabel komite audit memiliki t tabel sebesar -2,103 dengan koefisien sebesar -0,026 dan tingkat signifikansi 0,039 . Nilai sig. $=0,039<\alpha=0,05$. Berdasarkan nilai yang 
diperoleh dapat disimpulkan bahwa hipotesis 3 diterima yang menunjukkan bahwa variabel komite audit berpengaruh negatif terhadap tax avoidance.

Berdasarkan hasil uji statistik t pada tabel 6 diketahui bahwa variabel karakter eksekutif memiliki t tabel sebesar 2,174 dengan koefisien sebesar 174,350 dan tingkat signifikansi 0,023 . Nilai sig. $=0,023<\alpha=0,05$. Berdasarkan nilai yang diperoleh dapat disimpulkan bahwa hipotesis 4 diterima yang menunjukkan bahwa variabel karakter eksekutif berpengaruh positif terhadap tax avoidance.

Koefisien determinasi (Adjusted $R^{2}$ ) variabel bebas dalam penelitian ini dapat dilihat pada Tabel 7 berikut.

Tabel 7.

\section{Hasil Uji Koefisien Determinasi}

\begin{tabular}{llrrrr}
\hline Model & $\mathrm{R}$ & R Square & $\begin{array}{c}\text { Adjusted R } \\
\text { Square }\end{array}$ & $\begin{array}{c}\text { Std. Error of the } \\
\text { Estimate }\end{array}$ & Durbin Watson \\
\hline 1 & $0,73^{\mathrm{a}}$ & 0,537 & 0,537 & 0,1235009 & 1,943 \\
\hline \multicolumn{2}{l}{ Sumber: Data diolah, 2018} & & & &
\end{tabular}

Pada Tabel 7 menunjukkan koefisien determinasi sebesar 0,537 memiliki arti bahwa 53,7 persen variasi tax avoidance dipengaruhi oleh profitabilitas, leverage, komite audit, dan karakter eksekutif sedangkan sisanya 46,3 persen dipengaruhi oleh faktor-faktor lain yang tidak dimasukkan dalam model penelitian.

Uji kelayakan model (uji F) dilakukan untuk mengetahui apakah variabel independen berpengaruh terhadap variabel dependen secara simultan atau tidak. Hasil pengujian model dapat dilihat pada hasil analisis regresi pada Tabel 8 berikut. 
Tabel 8.

Hasil Uji Kelayakan Model (Uji F)

\begin{tabular}{llrrrrr}
\hline & & \multicolumn{2}{c}{ Surn of } & & & \\
& Model & Square & df & Mean Squre & F & Sig. \\
\hline $1 \quad$ Regression & 0,433 & 4 & 0,108 & 7,094 & $0,000^{\mathrm{a}}$ \\
& Residual & 3,035 & 199 & 0,015 & & \\
Total & 3,468 & 203 & & & &
\end{tabular}

Tabel 8 menunjukkan nilai $\mathrm{F}$ hitung sebesar 7,094 dengan signifikansi $\mathrm{F}$ sebesar 0,000 yang lebih kecil dari nilai $\alpha=0,05(0,000<0,005)$, sehingga dapat disimpulkan bahwa model ini layak digunakan dalam penelitian. Hasil ini menunjukkan bahwa variabel independen yang terdiri dari profitabilitas, leverage, komite audit, dan karakter eksekutif secara serempak berpengaruh terhadap variabel dependen yaitu cash effective tax rate sebagai proksi tax avoidance.

Berdasarkan hasil analisis pada tabel 4.7 menyatakan bahwa nilai koefisien profitabilitas positif sebesar 0,287 dengan tingkat signifikansi 0,012 yang lebih kecil dari taraf nyata penelitian yaitu 0,05 . Hasil tersebut menyatakan bahwa $\mathrm{H}_{0}$ ditolak dan $\mathrm{H}_{1}$ diterima sehingga dapat disimpulkan bahwa profitabilitas berpengaruh positif terhadap tax avoidance. Penelitian ini sejalan dengan penelitian yang dilakukan oleh Darmawan \& Sukartha (2014), Dewinta \& Ery (2016), dan Puspita \& Naniek (2017). Perusahaan dengan tingkat profitabilitas yang tinggi akan mampu untuk mengelola asetnya dengan baik yang nantinya akan memperoleh keuntungan dari insentif pajak atau pengelolaan pajak yang lain sehingga perusahaan tersebut akan terlihat melakukan tax avoidance (Darmawan \& Sukartha, 2014).

Tingginya ROA menyebabkan semakin besar laba yang dihasilkan perusahaan. Perusahaan yang memiliki laba yang besar akan sangat mudah untuk 
memanfaat celah dalam pengelolaan beban pajaknya. Laba yang tinggi akan menyebabkan semakin tingginya beban pajak yang harus dibayar perusahaan sehingga perusahaan melakukan praktik tax avoidance untuk mengurangi beban pajaknya.

Berdasarkan hasil analisis pada Tabel 6 menyatakan bahwa nilai koefisien leverage sebesar 0,106 dengan tingkat signifikansi $0,037<\alpha=0,05$. Hasil tersebut menyatakan bahwa $\mathrm{H}_{0}$ ditolak dan $\mathrm{H}_{2}$ diterima sehingga dapat disimpulkan bahwa leverage berpengaruh positif terhadap tax avoidance. Semakin tinggi leverage, maka beban bunga perusahaan juga akan meningkat sehingga dapat memengaruhi beban pajak perusahaan.

Perusahaan yang memilih menggunakan kebijakan leverage akan mendapatkan insentif pajak yang memanfaatkan beban bunga untuk memperkecil beban pajaknya. Hal ini berarti perusahaan dengan tingkat leverage yang tinggi cenderung melakukan tindakan tax avoidance sebagai akibat dari insentif pajak atas beban bunga yang diterima perusahaan untuk meminimalkan beban pajaknya.

Penelitian ini sejalan dengan penelitian yang dilakukan oleh Rachmitasari (2015), Nursari \& Sukarmanto (2016), Wijayanti \& Merkusiwati (2017), Daneshvar et al. (2017) serta Nugrahitha \& S. (2018) yang menyatakan bahwa leverage berpengaruh positif terhadap tax avoidance. Biaya bunga dapat mengurangi besarnya beban pajak, sehingga semakin tinggi tingkat leverage akan menyebabkan semakin besar praktik tax avoidance yang dilakukan. 
Hasil analisis pada Tabel 6 menyatakan bahwa nilai koefisien komite audit sebesar $-0,026$ dengan tingkat signifikansi $0,039<\alpha=0,05$. Hasil tersebut menyatakan bahwa $\mathrm{H}_{0}$ ditolak dan $\mathrm{H}_{3}$ diterima sehingga dapat disimpulkan bahwa keberadaan komite audit berpengaruh negatif terhadap tax avoidance. Penelitian ini sejalan dengan penelitian yang dialakukan oleh Dewi \& Jati (2014), Winata (2014), Rachmitasari (2015), Diantari \& Ulupui (2016), serta Noriska et al. (2017).

Menurut peraturan Bursa Efek Indonesia (BEI) mensyaratkan bahwa perusahaan sekurang-kurangnya memiliki komite audit berjumlah tiga orang. Jumlah komite audit yang tidak sesuai dengan peraturan BEI akan mengakibatkan peningkatan tindakan manajemen dalam melakukan tax avoidance untuk menekan beban pajaknya. Berdasarkan hasil analisis dan pengujian yang dilakukan menunjukkan bahwa komite audit dapat mencegah tindakan kecurangan yang dilakukan oleh manajemen karena komite audit berfungsi untuk melakukan pengawasan terhadap penyusunan laporan keuangan perusahaan. Semakin tinggi keberadaan komite audit dalam perusahaan maka kualitas good corporate governance di dalam suatu perusahaan akan semakin meningkat sehingga akan memperkecil terjadinya praktik tax avoidance yang dilakukan oleh perusahaan.

Berdasarkan hasil analisis pada Tabel 6 menyatakan nilai koefisien karakter eksekutif sebesar 174,350 dengan tingkat signifikansi $0,023<\alpha=0,05$. Nilai koefisien 174,350 menunjukkan bahwa karakter eksesutif berpengaruh positif terhadap tax avoidance. Hal ini menunjukkan bahwa semakin tinggi risiko perusahaan yang menjadi proksi dari karakter eksekutif, maka semakin tinggi pula 
tingkat tax avoidance yang dilakukan oleh perusahaan. Maka $\mathrm{H}_{0}$ ditolak dan $\mathrm{H}_{1}$ diterima sehingga dapat disimpulkan karakter eksekutif berpengaruh positif terhadap tax avoidance.

Penelitian ini sejalan dengan penelitian yang dilakukan oleh Maharani \& Suardana (2014), Swingly \& Sukartha (2015), Wiguna \& Jati (2017), dan Nugrahitha \& S. (2018). Berdasarkan hasil analisis dan pengujian yang dilakukan menunjukkan bahwa semakin eksekutif bersifat risk taker maka akan semakin besar praktik tax avoidance yang dilakukan. Karakter eksekutif dapat diukur dari tinggi rendahnya risiko perusahaan. Eksekutif yang bersifat risk taker akan cenderung untuk berani mengambil resiko termasuk resiko melakukan praktik tax avoidance.

Hasil penelitian ini secara teoritis dapat mengkonfirmasi Teori Agensi yang menjelaskan bahwa pemegang saham mengatur manajemen untuk menyusun laporan keuangan yang menguntungkan pemegang saham sehingga manajer akan berusaha untuk meningkatkan laba perusahaan dan meminimumkan beban pajaknya dengan melakukan praktik tax avoidance. Penelitian ini juga secara teoritis dapat mengkonfirmasi Teori Akuntansi Positif yang menjelaskan bahwa perusahaan dalam menjalankan usahanya tidak harus menggunakan prosedur akuntansi yang sama dengan perusahaan lain, namun perusahaan diberikan kebebasan untuk memilih alternatif prosedur akuntansi sehingga hal tersebut memotivasi perusahaan untuk melakukan praktik tax avoidance.

Perusahaan dengan tingkat profitabilitas yang tinggi memiliki pengaruh positif terhadap tax avoidance. Semakin tinggi tingkat profitabilitas sebuah 
perusahaan maka perusahaan tersebut semakin mudah untuk memanfaatkan celah dalam peraturan perpajakan sehingga perusahaan akan cenderung melakukan praktik tax avoidance untuk mengurangi beban pajaknya.

Perusahaan yang memiliki leverage yang tinggi berpengaruh positif terhadap tax avoidance yang artinya perusahaan melakukan tindakan tax avoidance karena adanya keuntungan dari beban utang yang tinggi untuk mengurangi beban pajak perusahaan.

Perusahaan dengan jumlah komite audit yang besar berpengaruh negatif terhadap tax avoidance. Perusahaan yang memiliki komite audit yang besar akan mengurangi tindakan kecurangan yang dilakukan oleh manajer sehingga praktik tax avoidance dapat diminimalkan.

Eksekutif yang memiliki karakter risk taker berpengaruh positif terhadap tax avoidance. Semakin eksekutif bersifat risk taker maka eksekutif cenderung lebih berani untuk mengambil resiko termasuk resiko untuk melakukan praktik tax avoidance.

Hasil penelitian ini dapat memberikan referensi bagi pemerintah untuk selalu melakukan pengawasan kepada perusahaan agar praktik tax avoidance dapat diminimalkan. Penelitian ini juga dapat dijadikan referensi bagi pihak regulator untuk membuat kebijakan baru yang lebih baik dan lebih efektif agar praktik tax avoidance dapat dikurangi atau tidak terulang kembali. Selain pemerintah dan regulator, penelitian ini juga dapat dijadikan referensi bagi perusahaan untuk patuh dan taat pada peraturan perpajakan yang berlaku. 


\section{SIMPULAN}

Profitabilitas berpengaruh positif terhadap tax avoidance. Semakin tinggi profitabilitas suatu perusahaan maka akan semakin besar praktik tax avoidance yang dilakukan karena perusahaan dengan profit yang besar akan lebih leluasa untuk memanfaatkan celah dalam pengelolaan beban pajaknya.

Leverage berpengaruh positif terhadap tax avoidance. Semakin tinggi leverage suatu perusahaan maka akan semakin besar praktik tax avoidance yang dilakukan. Kebijakan leverage digunakan perusahaan dalam perencanaan pajaknya karena adanya insentif dari beban bunga yang harus dibayar sehingga meminimumkan pembayaran pajak perusahaan.

Komite audit berpengaruh negatif terhadap tax avoidance. Semakin tinggi keberadaan komite audit dalam perusahaan maka semakin rendah praktik tax avoidance yang dilakukan karena komite audit dapat memonitor tindakan kecurangan yang dilakukan oleh manajemen.

Karakter eksekutif berpengaruh positif terhadap tax avoidance. Semakin eksekutif bersifat risk taker maka akan semakin besar praktik tax avoidance yang dilakukan. Karakter eksekutif dapat diukur dari tinggi rendahnya risiko perusahaan. Eksekutif yang bersifat risk taker akan cenderung untuk berani mengambil resiko termasuk resiko melakukan praktik tax avoidance.

Bagi peneliti selanjutnya hendaknya memperluas objek dan sampel penelitian sehingga dapat meningkatkan generalisasi hasil. Nilai adjusted $R^{2}$ dalam penelitian ini sebesar 53,7 persen yang menunjukkan bahwa masih banyak 
faktor lain yang berpengaruh pada tax avoidance namun belum diuji dalam penelitian ini.

Bagi perusahaan diharapkan lebih memerhatikan kebijakan leverage yang digunakan serta risiko yang ditanggung terkait dengan kewajiban beban pajaknya.

Bagi komite audit diharapkan untuk lebih meningkatkan independensi dalam memonitor manajemen sehingga tindakan kecurangan manajemen untuk melakukan praktik tax avoidance dapat diminimalkan.

Bagi perusahaan hendaknya memerhatikan tindakan eksekutif dalam mengambil keputusan karena adanya kemungkinan eksekutif cenderung berusaha untuk mengambil risiko yang tinggi untuk melakukan praktik tax avoidance.

\section{REFERENSI}

Anouar, D., \& Houria, Z. (2017). The Determinants of Tax Avoidance within Corporate Groups: Evidence from Moroccan Groups. International Journal of Economics, Finance and Management Sciences, 5(1), 57-65.

Butje, S., \& Tjondro, E. (2014). Pengaruh Karakter Eksekutif dan Koneksi Politik Terhadap Tax Avoidance. Tax and Accounting Review, 4(2), 1-9. https://doi.org/10.1186/s40543-014-0024-3

Carolina, V., Natalia, M., \& Debbianita. (2014). Karakteristik Eksekutif Terhadap Tax Avoidance Dengan Leverage. Jurnal Keuangan Dan Perbankan, 18(3), 409-419. Retrieved from http://jurkubank.wordpress.com

Cnnindonesia.com. (2017). Kontribusi Pajak Industri Manufaktur Capai Rp 224,95 Triliun. Www.Cnnindonesia.Com. Retrieved from https://m.cnnindonesia.com/ekonomi/20171029162847-92-

251965/kontribusi-pajak-industri-manufaktur-capai-rp22495-triliun

Daneshvar, M. E., Aghdaei, S. H., Baseri, M., \& Hassampur, D. (2017). Investigating the Effective Factors on Tax Avoidance in Companies Accepted in Tehran Stock Exchange. Jurnal Fikrah, 8(1), 421-433.

Darmawan, I. G. H., \& Sukartha, I. M. (2014). Pengaruh Penerapan Corporate Governance, Leverage, Return On Assets dan Ukuran Perusahaan pada 
Penghindaran Pajak. E-Jurnal Akuntansi Universitas Udayana, 9(1), 143161.

Derashida, C., \& Zhang, H. (2003). Effective tax rates and the "industial policy" hypothesis: Evidence from Malaysia. Journal of International Accounting, Auditing \& Taxation, 12(1), 45-62. https://doi.org/10.1016/S10619518(03)00003-X

Dewi, N. N. K., \& Jati, I. K. (2014). Pengaruh Karakteristik Eksekutif, Karakteristik Perusahaan, dan Dimensi Tata Kelola Perusahaan yang Baik pada Tax Avoidance Di Bursa Efek Indonesia. E-Jurnal Akuntansi Universitas Udayana, 6(2), 249-260.

Dewinta, I. A. R., \& Ery, P. S. (2016). Pengaruh Ukuran Perusahaan, Profitabilitas, Leverage dan Pertumbuhan Penjualan Terhadap Tax Avoidance. E-Jurnal Akuntansi Universitas Udayana, 14(3), 1584-1613.

Diantari, P. R., \& Ulupui, I. A. (2016). Pengaruh Komite Audit, Proporsi Komisaris Independen, dan Proporsi Kepemilikan Institusional Terhadap Tax Avoidance. E-Jurnal Akuntansi Universitas Udayana, 16(1), 702-732.

Fadhilah, R. (2014). Pengaruh Good Corporate Governance Terhadap Tax Avoidance (Studi Empiris pada Perrusahaan Manufaktur yang Terdaftar di BEI 2009-2011). Jurnal Akuntansi Universitas Negeri Padang, 2(1).

Hanafi, U., \& Harto, P. (2014). Analisis Pengaruh Kompensasi Eksekutif, Kepemilikan Saham Eksekutif dan Preferensi Risiko Eksekutif terhadap Penghindaran Pajak Perusahaan. Diponegoro Journal of Accounting, 3(2), 111. https://doi.org/10.1021/acs.jctc.6b00289

Hasan, I., H, C. K., Wu, Q., \& Zhang, H. (2017). Does Capital Matter in Corporate Decision? Evidence from Corporate Tax Avoidance. Journal of Accounting Research, 55(3), 629-668. https://doi.org/https://doi.org/10.1111/1475-679X.12159

Jacob, F. (2014). An Empirical Study of Tax Evasion and Tax Avoidance: A Critical Issue in Nigeria Economic Development. Journal of Economics and Sustainable Development, 5(18), 22-27. Retrieved from www.iiste.org

Kartana, I. W., \& Wulandari, N. G. A. S. (2018). Pengaruh Karakter Eksekutif, Karakteristik Perusahaan dan Corporate Governance Terhadap Tax Avoidance. Jurnal KRISNA: Kumpulan Riset Akuntansi, 10(1), 1-13. https://doi.org/10.22225/kr.10.1.708.1-13

Kemenperin.go.id. (2018). Lampaui 31 Persen, Industri Manufaktur Penyumbang Pajak Terbesar. Www.Kemenperin.Go.Id. Retrieved from 
https://www.kemenperin.go.id/artikel/18630/Lampaui-31-Persen,-IndustriManufaktur-Penyumbang-Pajak-Terbesar

Kompas.com. (2014). Coca Cola Diduga Akali Setoran Pajak. Www.Kompas.Com. Retrieved from https://ekonomi.kompas.com/read/2014/06/13/1135319/CocaCola.Diduga.Akali.Setoran.Pajak.

Kompas.com. (2014). Ini Alasan Kasus Pajak Asian Agri Digiring ke Pelanggaran Administrasi. Www.Kompas.Com. Retrieved from https://ekonomi.kompas.com/read/2014/01/24/1644374/Ini.Alasan.Kasus.Paj ak.Asian.Agri.Digiring.ke.Pelanggaran.Administrasi.

Maharani, I. G. C., \& Suardana, K. A. (2014). Pengaruh Corporate Governance, Profitabilitas, dan Karakter Eksekutif Tax Avoidance Perusahaan Manufaktur. E-Journal Akuntansi Universitas Udayana, 9(2), 529-539.

Marfirah, D., \& BZ, F. S. (2016). Pengaruh Corporate Governance dan Leverage Terhadap Tax Avoidance Pada Perusahaan Manufaktur yang Terdaftar di Bursa Efek Indonesia Tahun 2011-2015. Jurnal IlmiahMahasiswa Ekonomi Akuntansi, 1(2), 91-102.

Mehrani, S., \& Seyyedi, S. . (2014). Investigating The Relationship Between Tax Avoidance And Tax Differences In Companies Listed On The Tehran Stock Exchange. Journal Accounting and Auditing Research, 6, 50-75.

Mulyani, S., Darminto, \& N.P, M. . W. E. (2014). Pengaruh Karakteristik Perusahaan, Koneksi Politik, dan Reformasi Perpajakan Terhadap Penghindaran Pajak (Studi Pada Perusahaan Manufaktur yang Terdaftar di Bursa Efek Indonesia Tahun 2008-2012). Jurnal Mahasiswa Perpajakan Universitas Brawijaya, 2(1).

Noriska, S. F., Pratomo, D., \& Yudowati, S. P. (2017). Pengaruh Kepemilikan Manajerial, Komisaris Independen dan Komite Audit Terhadap Tax Avoidance. E-Journal Akuntansi Universitas Udayana, 21(3).

Nugrahitha, A. I. M., \& S., H. B. (2018). Pengaruh Profitabilitas, Leverage, Corporate Governance dan Karakter Eksekutif pada Tax Avoidance. EJurnal Akuntansi Universitas Udayana, 22(3), 2016-2039.

Nursari, M., \& Sukarmanto, E. (2016). Pengaruh Profitabilitas , Leverage, dan Kepemilikan Institusional terhadap Tax Avoidance ( Studi Empiris pada Perusahaan Kimia yang Terdaftar di Bursa Efek Indonesia ( BEI ) pada Periode Tahun 2009-2016 ). Prosiding Akuntansi, 3(2), 259-266.

Pohan, H. T. (2009). Analisis Pengaruh Kepemilikan Institusi, Rasio Tobin Q, 
Akrual Pilihan, Tarif Efektif Pajak, dan Biaya Pajak Ditunda terhadap Penghindaran Pajak Pada Perusahaan Publik. Jurnal Informasi, Perpajakan, Akuntansi Dan Keuangan Publik, 4(2), 113-135.

Puspita, N. L. D., \& Naniek, N. (2017). Pengaruh Ukuran Perusahaan, Leverage, Profitabilitas, dan Corporate Soacial Responsibility Terhadap Penghindaran Pajak (Tax Avoidance). E-Jurnal Akuntansi Universitas Udayana, 21(1), 830-859.

Putra, I. G. L. N. D. C., \& Merkusiwati., N. K. L. A. (2016). Pengaruh Komisaris Independen, Leverage, Size, dan Capital Intensity Ratio Pada Tax Avoidance. E-Jurnal Akuntansi Universitas Udayana, 17(1), 690-714.

Putri, V. R. (2017). Pengaruh Leverage, Profitability, Ukuran Perusahaan, dan Proporsi Kepemilikan Institusional Terhadap Tax Avoidance. Jurnal Ekonomi Manajemen Sumber Daya, 19(1), 1-11.

Rachmitasari, A. F. (2015). Pengaruh Return On Assets, Leverage, Corporate Governance, Ukuran Perusahaan dan Kompensasi Rugi Fiskal. Universitas Muhammadiyah Surakarta.

Swingly, C., \& Sukartha, I. M. (2015). . Pengaruh Karakter Eksekutif, Komite Audit, Ukuran Perusahaan, Leverage, dan Sales Growth pada Tax Avoidance. E-Jurnal Akuntansi Universitas Udayana, 10(1), 47-62.

Tempo.co. (2010). Jalan Panjang Kasus Pajak KCP. Www.Tempo.Co. Retrieved from https://www.bisnis.tempo.co/amp/224682/jalan-panjang-kasus-pajakkpc.

Wiguna, I. P. P., \& Jati, I. K. (2017). Pengaruh Corporate Social Responsibility, Preferensi Risiko Eksekutif, dan Capital Intensity Pada Penghindaran Pajak. E-Jurnal Akuntansi Universitas Udayana, 21(1).

Wijayanti, Y. C., \& Merkusiwati., N. K. L. A. (2017). Pengaruh Proporsi Komisaris Independen, Kepemilikan Institusional, Leverage, dan Ukuran Perusahaan Pada Penghindaran Pajak. E-Jurnal Akuntansi Universitas Udayana, 20(1), 699-728.

Winata, F. (2014). Pengaruh Corporate Governance Terhadap Tax Avoidance Pada Perusahaan Yang Terdaftar Di Bursa Efek Indonesia Tahun 2013. Tax \& Accounting Review, 4 (1)(1), 1-11. https://doi.org/10.2307/2692184 